\title{
Economic Rents and Legitimacy: Incorporating Elements of Organizational Analysis Institutional Theory to the Field of Business Strategy
}

\author{
Marco Aurélio Lima de Queiroz* \\ E-mail address: marcoqueiroz@gvmail.br \\ Escola de Administração de Empresas de São Paulo - Fundação Getúlio Vargas \\ São Paulo, SP, Brazil \\ Flávio Carvalho de Vasconcelos \\ E-mail address: fvasconcelos@fgvsp.br \\ Escola de Administração de Empresas de São Paulo - Fundação Getúlio Vargas \\ São Paulo, SP, Brazil \\ Rafael Guilherme Burstein Goldszmidt \\ E-mail address: rafaelgoldszmidt@gvmail.br \\ Escola de Administração de Empresas de São Paulo - Fundação Getúlio Vargas \\ São Paulo, SP, Brazil
}

\begin{abstract}
Are sources of economic rent, as defined by the prevalent business strategy paradigm, sufficient to attain and maintain superior returns? The perspective developed within the conceptual framework of the Institutional Theory may offer managers a contribution towards understanding the strategy process and its potentialities, particularly by stressing the leading role played by legitimacy, the influence of many institutional spheres, the isomorphic pressures, ceremonial behavior and decoupling, among other elements, that mainstream business strategy fails to address directly, but which may have a significant effect on firm performance. We advance that these elements must be accounted for in the pursuit and acquisition of economic rents, even if the ability to articulate them purposefully is constrained by rationality, agency conditions and the manager's social embeddedness.
\end{abstract}

Key words: strategy; institutional theory; legitimacy; institutional strategy.

Received 21 February 2006; received in revised form 30 May 2006.

Copyright (C) 2007 Brazilian Administration Review. All rights reserved, including rights for translation. Parts of this work may be quoted without prior knowledge on the condition that the source is identified.

* Corresponding author: Marco Aurélio Lima de Queiroz

Escola de Administração de Empresas de São Paulo, Av. 9 de Julho, 2029, 11º andar, Bela Vista, São Paulo/SP, 01313-902, Brazil. 


\section{INTRODUCTION}

In traditional economics, as well as in a large portion of Business Strategy theory, the main purpose of a firm is to maximize profit. Managers are expected to conceive strategies leading to better positions - as compared to competitors - in attractive industries; to identify and utilize distinctive resources (or competences), through which they may achieve sustainable above-average returns.

Generally speaking, the prevalent thinking in the field of Business Strategy lies in assumptions that may be questionable from the perspective of Organizations Theory in general and Institutional Theory in particular. Most Business Strategy studies emphasize achieving economic rents through the pursuit of efficiency, dealing with the constraints imposed by the technical environment. Such studies usually understand that agents have a broad ability to apprehend the social context in which they operate, and are endowed with high capacity to intervene in social reality and to control their interventions.

This paper proposes that achieving and maintaining above-average returns depends not only on successfully obtaining sources of economic rent, but also on obtaining and retaining legitimacy, whose management must not be neglected. Legitimacy is a core topic in Institutional Theory and is frequently disregarded by dominant approaches in the Business Strategy field. The purpose of this paper is to show that a combined understanding of the technical and institutional facets of the environment and of organizations, as well as of the condition and possibilities of agency, is pertinent and relevant to those that would formulate and implement business strategies, thereby confirming the need for a strong theoretical connection between the fields of Organizations Theory and Strategy.

Although several texts exist on strategic choice and institutional pressures, few articulate institutionalist arguments vis-à-vis the different theoretical schools of Business Strategy, particularly regarding strategy formulation and execution.

\section{THE FIELD OF BUSINESS STRATEGY}

Given the diverse theoretical schools of thought in Business Strategy, it is worth introducing them briefly, highlighting their characteristic assumptions and hypotheses.

According to Vasconcelos and Cyrino (2000), the field of Business Strategy is based on the understanding (and pursuit) of a competitive advantage associated with market failures. The concept of strategy would be unnecessary, and even dysfunctional, if the market were perfectly competitive, as described in the conceptual framework of neo-classical economics. What good would strategy do if the decisions of firms were concentrated on the allocation of fungible resources across finite alternatives known to all, with given technology and know how, and with perfectly fluid diffusion processes?

The influence of economics in the field of Business Strategy has been very significant (Besanko et al., 2000; Rumelt, Schendel, \& Teece, 1991). Ghemawat (2002), for example, outlines the historical development of the field with an almost exclusively economic emphasis, without significant references to possible cultural and cognitive influences.

In the first half of the twentieth century, deviations from the promises of the perfect competition model - or market failures - are explored by the school of thought that became known as Industrial Organization (Bain, 1956; Mason, 1939) and, more recently, by Caves (1980) and Porter $(1980,1985)$. Exploration of these imperfections provides a basis for competitive advantage to be understood as obtaining monopoly rents in markets with little competition by favorable positioning in strategic groups (Caves \& Porter, 1977). This school of thought is prevalent, in absolute terms, in the study of the main strategic management references quoted in the Strategic Management Journal - SMJ, but has been losing ground since the 1990s (Ramos-Rodriguez \& Ruiz-Navarro, 2004). 
The concept that qualitative differences among firms can be charged to specific resources is a central break from theories focused on monopoly rents, which credit performance variations among firms to external factors such as industry structure. Since the 1980s, scholars associated with the Industrial Organization school and the proponents of the Resource Based View - RBV have been engaged in a heated debate. According to the RBV, as originally posited by Penrose (1959) and, subsequently, by Wernerfelt (1984), Peteraf (1993) and Barney (1986a, 1991), firms' sources of competitive advantage lie, primarily, in the resources and competences of individual firms, and only secondarily in the structure of the industries in which they operate.

The view of competitive advantage as the result of market failures remains in the RBV, but it shifts from the products market to the factors market (Barney, 1986a, 1991) and is reflected in Ricardian rents. This school attained a central position in theoretical references of the SMJ since the second half of the 1990s (Ramos-Rodriguez \& Ruiz-Navarro, 2004) laying the foundations for a possible new theory of the firm (Conner, 1991).

The process of resource accumulation development in organizations is discussed by Dierickx and Cool (1989) and developed theoretically by Teece, Pisano and Shuen (1997) from the perspective of dynamic capabilities. Based on the general concept of the firm as a set of resources, this model analyzes the relationships between decision processes, actions, and managerial consequences in terms of the formation, conservation and destruction of resources "in a Schumpeterian world of innovationbased competition, price/performance rivalry, increasing returns and the creative destruction of existing competences” (Teece, Pisano, \& Shuen 1997, p. 509; Schumpeter, 1934). This emphasizes the role strategic management plays in the adaptation and reconfiguration of organizational resources and skills to face the demands of a dynamic, mutable external environment. Therefore, unlike the OI and RBV views, the view of dynamic capabilities creates an important possibility of convergence between strategy and organizations theory (Vasconcelos \& Cyrino, 2000) that supports the proposal we advocate here.

Rumelt, Schendel and Teece (1991) highlight Transaction Costs Economics (Coase, 1937; North, 1993; Williamson, 1985) as a point of approximation for Business Strategy, Economics and Organizations Theory, when considering limited rationality (March, 1978; Simon, 1947), opportunistic behavior and the role of institutions to alleviate uncertainty (North, 1993). Transaction costs analysis is a cross-disciplinary approach that proposes to combine economics, organizations theory and contracts law, with emphasis on the translation of the implications of limited rationality and the role of institutions in terms of efficiency and cost. Still, economic thinking remains prevalent, as Granovetter (1985) points out in his critique of this view.

On developing an overview of the field of Business Strategy, Mintzberg, Ahlstrand and Lampel (1998) makes reference to ten schools of strategic thinking. Some are characterized by their prescriptive orientation, that is, their concern with how strategies are to be formulated, and what their content should be (schools of design, planning and positioning). Others are descriptive, focusing on the strategy formulation process (the entrepreneurial, cognitive, learning, power, cultural and environmental schools). He further points out the existence of a configuration school, which he supports, and is presented as an attempt to merge the others: it appreciates planning, but acknowledges its limitations; it takes place deliberately at times, or in an emerging way at others. It argues that as a strategy is implemented, a series of developments deviate from its originally intended path, creating room for the emergence of new patterns that may imply new strategies (emerging strategies). An emerging strategy is, in essence, an unplanned strategy, a line of action that the organization only perceives as strategic as it unfolds or even after the fact (Mintzberg, 1978).

Like Vasconcelos and Cyrino (2000), we can also see in Mintzberg the proposition of a convergence between the field of Business Strategy and Organizations Theory. This is even clearer in a previous work (Mintzberg, 1994), where he points out a series of strategic planning fallacies: the fallacy of prediction (predictability of the environment, action course and its consequences); the fallacy of detachment (the strategist remaining at arm's length and retaining an objective vision or 
reality) and the fallacy of formalization (the possibility of formalizing the strategy and its implementation process).

In an attempt to organize a discussion of the diversity of the field of Business Strategy, Whittington (1993) presents four generic perspectives of strategy: classical, evolutionary, processual and systemic, which differ in terms of results (what strategy is for - economic focus or diverse objectives) and processes (how it develops - deliberate or emerging). It is worth noting, in line with the purpose of this work, that the core message of the systemic perspective, according to Whittington, is that the strategy must be sociologically sensible.

Whittington notes that these different perspectives, each with distinct implications for managerial action, are all capable of accumulating a significant body of evidence in their favor. Faced with such ambiguity, it befalls managers to choose the theoretical description of the activity and human environment that best fit their worldview, their personal theory of action (Argyris \& Schon, 1978).

The field of Business Strategy, as described, comprehends many theoretical schools; little consensus exists, which may help to account for the low levels of academic productivity seen in recent years (Boyd, Finkelstein, \& Gove, 2005; Pfeffer, 1993). Despite the diversity, no works are to be found emphasizing aspects relative to the dynamics and relevance of institutions to the strategy formulation and execution process. Evidence of this statement can be found in the empirical study of RamosRodrigues and Ruiz-Navarro (2004), who failed to identify any references specifically associated with the Institutional Theory among the most frequent quotes published in the Strategic Management Journal - SMJ.

\section{The InSTITUTIONAL THEORY AND THE DisCusSion OVER AGENCY AND STRUCTURE}

According to DiMaggio, "The distinguishing contribution of Institutional Theory rests in the identification of causal mechanisms leading to organizational change and stability on the basis of preconscious understandings that organizational actors share, independent of their interests" (1988, p. 3).

Institutional Theory expands in the realm of organizations in the 1970s, as an extension of the previous decade's intellectual revolution, which introduced the concept of open systems into organizations studies (Katz \& Kahn, 1966; Thompson, 1967), pointing out the importance of context or environment inasmuch as "it constrains, shapes, penetrates and renews the organization. . . organizations were seen to be more than production systems; they were social and cultural systems" (Scott, 2001 p. xx). The influence of the concept of the social construction of reality (Berger \& Luckmann, [1967] 1998), and of limited rationality (March, 1978; Simon, 1947) must also be highlighted.

The early institutionalists distanced themselves from the neo-classical view, which prevails in the conception of organizations as closed systems, on four key points: instead of perfect competition and unique equilibrium, they postulate market power and indetermination; economic agents' preferences are not regarded as individual decisions, but as a socially constructed process, shaped by social institutions; instead of utilitarian assumptions, regarded as naive, they propose a behavioral realism; and, finally, they replace universal generalizations with context (time and space) (Jacobby, 1990).

Scott (2001) notes differences in the definition of an institution, due to different concepts of the nature of social reality and social order and the types and extent of the agents' rationality as they make choices. According to his definition, "institutions are social structures that have attained a high degree of resilience; institutions are composed of cultured-cognitive, normative and regulative elements that, together with associated activities and resources, provide stability and meaning to social life; institutions are transmitted by various types of carriers, including symbolic systems, 
relational systems, routines and artifacts; institutions operate at multiple levels of jurisdiction...(they) are subject to change processes, both incremental and discontinuous” (2001, p. 48).

It is important to note that, unlike the analytical strategies and the assumptions that prevailed in Organizations Theory at the time, the early institutional approaches emphasize factors that made it unlikely for agents to recognize their interests or act according to them. They also address the circumstances that constrain actors' ability to recognize their interests and act accordingly, particularly "the limits on cognition and coordination, which make it difficult or impossible for actors to understand the relationship between means and ends" (DiMaggio, 1988, p.5). According to this view, structure prevails over (capacity for) agency.

DiMaggio attempts to relocate interest and agency to a central position in Institutional Theory, suggesting that institutionalization be seen as "a product of the political efforts of actors to accomplish their ends and that the success of an institutionalization project and the form that the resulting institution takes depend on the relative power of the actors who support, oppose, or otherwise strive to influence it" (1988, p. 13). According to DiMaggio, the process follows "an internal logic of contradiction, such that the success of an institutionalization process creates new sets of legitimate actors who, in the course of pursuing distinct interests, tend to delegitimate and deinstitutionalize aspects of the institutional forms to which they owe their own autonomy and legitimacy” (p.13).

The nature of the relationship between agency and structure is a core issue in the debate of the Institutional Theory and in the field of Business Strategy alike; its implications are clear to the discussion of the possibilities of strategy formulation and execution, which is the focus of this study.

Giddens (1989) suggests that the relationship between agency and structure is of a recursive nature, arguing that structure is not a product of independent human activity by itself, an object outside the subject, but rather "a set of rules and resources that can only exist as a space-time presence, in its examples in social practices, and as mnemonic traits that guide agents' conduct” (p. 442). Structure is the medium and the result of the conduct it organizes recursively. The relationship between subject (agent) and object (structure) must be reconceptualized as one of duality, rather than dualism.

In line with Giddens' duality proposition, Sewell (1992) explores the possibilities for agency, identified as: the participation of social agents (agents) in several (institutional) spheres that are connected or compete for resources, the transposition of schemes from one sphere to another and the interpretation of social agents of the meaning of resources.

Whittington (1992) offers an extensive analysis of published organizations studies texts that report on Giddens' proposition (Theory of Structuration). He understands that researchers tend to perceive institutionalization processes as promoting resolution and accommodation; he suggests taking up structurationism, that is, the acceptance of structural conflict and stress between agency and structure. He recommends a sociological realism that emphasizes both agency and structure, avoiding the determinism / voluntarism dichotomy that marks several theoretical schools (Whittington, 1988). According to him, agency possibilities relate to the internal ambiguity and plurality of the rules that govern the reproduction of a specific set of social structures, as well as to the contradictions brought about by rules and resources that agents import from other social systems in which they take part (their social identities). The reflexivity of agents eventually stands as a resource to try to deliberately change the system's reproduction.

In another review of published works on strategic management using Structuration Theory between 1995 and 2000, Pozzebon (2004) concludes that Giddens' propositions were incorporated into other analytical perspectives, enhancing the roles of both agency and structure in the development of what the author calls integrating approaches.

The view that the relationship between agency and structure is of a chiefly recursive nature and mediated by interpretation (Machado-da-Silva, Fonseca, \& Crubellate, 2005) challenges the prevalent Business Strategy argument that strategy determines structure (Chandler, 1962). Simultaneous emphasis on agency and structure questions the validity of the assumptions of several of the field's 
theoretical schools. Mintzberg suggests that "structure follows strategy. . . like the left foot follows the right” (1990, p. 183).

\section{Institutional Pressures AND SPACE fOR StRATEGic ReSPONSES}

Organizations endure pressures from the institutional environment that are characterized as isomorphic mechanisms: “. . . structural change in organizations seems less and less driven by competition or by the need for efficiency. Instead, we will contend, bureaucratization and other forms of organizational change occur as the result of processes that make organizations more similar without necessarily making them more efficient” (DiMaggio \& Powell, 1983, p. 147). Such pressures are intrinsically associated with institutionalization processes: "highly structured organizational fields provide a context in which individual efforts to deal rationally with uncertainty and constraint often lead, in the aggregate, to homogeneity in structure, culture and output” (DiMaggio \& Powell, 1983, p. 147).

Meyer and Rowan (1977) point out that "institutional rules function as myths which organizations incorporate, gaining legitimacy, resources, stability, and enhanced survival prospects” (p. 340). Any conflicts between the pursuit of technical efficiency and the maintenance of institutional rules (legitimacy) can be resolved by adopting ceremonial behavior, by decoupling (loosening) internal control, based on a trust and good-faith reasoning. That is, once it is believed that the agents involved are committed to the organization's success (or survival), there can be tolerance and compromises so that conflict does not become too severe, capable - paradoxically at first sight - of jeopardizing the organization's long-term effectiveness.

If, on the one hand, isomorphic pressures appear to enhance the role of structure, constraining the agent, on the other hand, ceremonial behavior reveals possibilities of choice. Oliver (1991) discusses how responses to institutional pressure may vary from passive conformity to active resistance, depending on the nature and context of the pressures. She identifies as possible strategic responses: acquiescence, compromise, avoidance, defiance and manipulation. Developing this view, Scott (2001) notes that responses may be collective, rather than only individual.

Another strategic response possibility is inherent to the agent's action, inasmuch as such action always contributes to the institutionalization (and de-institutionalization) of social structures, taking the structurationist view discussed earlier.

In this sense, Oliver (1992) points out the conditions that may encourage and/or contribute to institutional change processes: functional (performance issues), political (changes in interests or in the power distribution that upheld institutional arrangements) and social (groups differentiation, heterogeneous or diverging practices and beliefs). Seo and Creed (2002) note that changes are a result of human practice and institutional contradictions (norms institutionalized earlier or in different contexts may lead to inefficiency, loss of adaptation, institutional incompatibilities and misalignment of agents' interests). The pursuit of better adaptation conditions would imply a political dispute among the several constituents.

The space for strategy formulation and execution is thereby outlined; the environment, in its institutional facet, exerts pressures that may constrain choice; agents, however, have room to maneuver. They are not always aware of the pressures suffered or the possible alternatives. And, whether they like it or not, and willfully or not, they constantly contribute to the institutionalization and de-institutionalization of the social structures in which they are embedded. 


\section{LEGITIMACY AS A STRATEGIC RESOURCE}

Weber (1999) was among the first social theorists to draw attention to the central role legitimacy plays in social life, by pointing that forms of action are guided by a belief in the existence of a legitimate order, a set of identifiable maxims providing models actors regard as somehow mandatory or exemplary to themselves.

Organizations need legitimacy: "organizations require more than material resources and technical information if they are to survive and thrive in their social environments. They also need social acceptability and credibility” (Scott, 2001, p.58).

An organization's legitimacy can be understood as "a generalized perception or assumption that the actions of an entity are desirable, proper, or appropriate within a socially constructed system of norms, values, beliefs and definitions" (Suchman, 1995, p. 574). Legitimacy affects not only how individuals act in relation to organizations, but how they understand them. Therefore, many audiences perceive legitimate organizations not only as more valuable, but also as more meaningful, predictable and trustworthy. Legitimacy in this context can be regarded as a valuable resource under the more traditional criteria of the RBV, even if more careful analysis reveals that legitimacy is in fact a special resource that is realized by permitting differentiated access to other resources, acting, in this sense, as a meta-resource (a resource that gives access to other resources, Teece, Pisano, \& Shuen, 1997).

A managerial issue that arises in the process of strategy formulation and execution is the possibility of managing legitimacy. Suchman (1995) discusses two possibilities, despite highlighting their limitations, particularly as regards "unintended consequences and unexpected feedback loops that may plague attempts to manipulate legitimacy in a narrowly instrumental way” (p. 573).

According to the strategic approach, legitimacy is seen as an operating resource organizations draw from their cultural environments and employ in the pursuit of their objectives (Ashforth \& Gibbs, 1990; Oliver, 1991, 1997; Pfeffer, 1981; Suchman, 1995). Managers may act to gain, maintain or repair three different kinds of legitimacy: pragmatic (meeting the interests of constituents), moral (doing what must be done) and cognitive (this is how it is supposed to be).

The institutional approach (DiMaggio \& Powell, 1983; Meyer \& Rowan, 1977), in turn, portrays legitimacy as a set of constitutive beliefs (Suchman, 1988); legitimacy and institutionalization are both related, they empower organizations mainly by making them appear natural and meaningful: "access to resources is largely a by-product” (Suchman, 1995, p. 576). Neilsen and Rao (1987) define legitimation as a collective meaning creation process, criticizing the view of the agent as being capable of manipulating a passive set of actors; they argue that legitimacy must be approached as a complex process of social construction of reality.

"Organizational legitimacy is a valued but problematic resource" argue Ashforth and Gibbs (1990, p. 191). According to these authors, the phenomenon of the pursuit of legitimacy can be seen as a series of combined vicious cycles. Firstly, when an organization seeks legitimacy, the many constituents observe it more strictly, which gives less room to deal with deviations from constituents' expectations and even less decoupling opportunities (Meyer \& Rowan, 1977). Secondly, inasmuch as legitimacy is associated with resources, defending or expanding it becomes more difficult. Culture, infrastructure, commitments and time constraints may even further reduce the organization's capacity to respond. Thirdly, the more problematic legitimacy becomes, the more skeptical constituents may be toward legitimation attempts. Combination of these three dynamics may lead managers into bumbling, nervous or excessively zealous legitimation attempts, thereby validating the constituents' skepticism (Ashforth \& Gibbs, 1990). 


\section{INSTITUTIONAL STRATEGY}

Whether as a resource, a meta-resource or a condition arising from a process, legitimacy matters to managers. The ability to manage it may be open to discussion, but not ignored.

Defending the institutional strategy view, Lawrence (1999) argues: "the concept of institutional strategy is important for the widened and wizened strategic lens it provides. An understanding of the importance of institutional strategy and the contingencies associated with its accomplishment will aid managers in dealing with the competitive context in which they operate. The often taken-for-granted rules and standards that situate a firm with respect to other firms, customers, suppliers, and other organizations inevitably provide both opportunity and constraint. A conception of these rules and standards as socially constructed, and consequently manageable opens up strategic possibilities. At the same time, however, the nature of institutional structures inevitably makes change difficult” (p. 185186).

Lawrence, Winn and Devereaux Jennings (2001) argue that the temporal dynamics of institutionalization spheres (practices, rules or technologies) is important, can be identified and predicted, and that knowledge of this dynamics would enable managers to carry out strategic action. The mechanisms used in institutionalization efforts - influence, force, discipline or domination depend on the target's (organizations; individuals) capacity for agency and on how power is wielded whether episodically (demanding continuous application of power to sustain itself) or systemically (embedded into routine systems that do not require constant activation), with implications for speed of institutionalization and for the stability of those spheres.

Still from the same voluntaristic viewpoint, but perceiving the institutional context as more of a constraint, Oliver (1997) points out "that a firm's ability to generate rents from resources and capabilities will depend primarily on the firm's effectiveness in managing the social context of these resources and capabilities" (p. 711). Normative rationality, institutional insulation mechanisms (low level of cultural or political support to resource-related decisions) and isomorphic pressures act as suboptimizers in resource selection and acquisition decisions.

Elsbach and Sutton (1992), on the other hand, explore a situation where institutional strategy, through deliberate management of the impressions of the other constituents, creates unprecedented possibilities to obtain resources for the social organizations. These organizations achieved great exposure after their members carried out illegal activities, but their rules adopted the appearance of institutional conformity as a tactic and were successful in decoupling from the illegitimate acts performed.

The institutional strategy, however, can be seen from a less voluntaristic perspective. Peng (2003) suggests that "the strategic choices for the three major types of firms (new, entrant and established entrepreneurs), which may constitute an organizational field, are identifiable and predictable” (p. 291). In a way, therefore, institutional conditions determine choices. Inasmuch as this is observed, it is worth asking whether such strategies are not closer to institutionalized strategies, that is, alternatives regarded as natural or as the only viable choice, and whether the agent is not, therefore, culturally determined (Beckert, 1999; Zucker, 1983). While exploring the implications of the Institutional Theory for strategic thinking, Crubellate, Grave and Mendes (2004) discuss this view as a third school, in addition to voluntarism and determinism.

Stone and Brush (1996) discuss the dilemma of planning in ambiguous contexts. Informal and vague plans allow gaining the commitment of many constituents with distinct interests; at the same time, there is a need to show formalized managerial practices to acquire legitimacy in the face of critical resource providers. What does it represent: institutional strategy or institutionalized strategy?

The adoption of new techniques and the phenomenon of managerial fads are studied by Wood and Caldas (2002) and Abrahamson (1996), in both cases from a perspective that avoids excessive 
voluntarism or determinism. Agents find themselves subject to institutional pressures that at once condition and enable their action; consultants articulate discourse that require legitimacy before their future buyers (Abrahamson, 1996); these, in turn, adopt techniques with a greater or lesser degree of critical analysis (Wood \& Caldas, 2002), and are driven by several motivations, whether intentional or not. This brings plenty of room for institutional strategies and institutionalized strategies.

\section{INSTITUTIONAL ENTREPRENEURSHIP}

In light of the relevance of institutional pressures and the need organizations have of legitimacy, an important phenomenon to discuss in the context of institutional strategy is entrepreneurship. "The question left unanswered, however, is how initial and early adopters are enabled to be different" (Sherer \& Lee, 2002, p. 104).

According to Sherer and Lee (2002), the scarcity of resources motivates, and legitimacy enables, institutional change; in their study, they find that innovation has occurred with prestigious companies that faced scarce resources and had the legitimacy to change the rules and resources. Lounsbury and Glynn (2001) argue that the institutional strategy of new entrepreneurs resides in the narratives they tell about their capital stock in order to legitimize their businesses; these narratives allow acquiring new capital and subsequently generating wealth and accumulation (of new capital). Construction of an identity that is perceived as legitimate involves balancing the need to sustain a strategic differentiation, on the one hand, and the need to align with the norms and constraints imposed by structural factors at the level of the industry in which they operate, on the other.

Aldrich and Fiol (1994) discuss the constraints entrepreneurs face in emerging industries, particularly the lack of cognitive and socio-political legitimacy. They suggest that entrepreneurs should strive to strike a balance between the attempt to differentiate from the others and the need for cognitive efforts from all the actors in the emerging industry to portray the new activity as familiar and trustworthy in order to survive as a group.

Institutional entrepreneurship therefore involves ambiguity and contradiction; seeks differentiation, but needs isomorphism; presents itself as an alternative to institutionalized choice, but success has institutionalized it. Stinchcombe (1965) was among the first to acknowledge the strong influence of social and institutional conditions on the structure of an organization in the early period after its foundation (imprinting), and the trend of such traits persisting, becoming institutionalized.

\section{BUSINESS STRATEGY AND INSTITUTIONAL THEORY}

Having acknowledged the pertinence and relevance of the institutional view to the strategy formulation and execution process, we must now analyze the impact of its incorporation into the theoretical references of Business Strategy addressed here, namely Industrial Organization, the Resource-Based View (RBV) and the Dynamic Capabilities theory. A far too complex task for the purposes of this work, but too important to ignore.

The conceptual framework of Industrial Organization lies based on the Structure-ConductPerformance assumption (Bain, 1956; Mason, 1939). The manager's agency is strongly constrained by the industrial structure in which the firm operates, and which offers - among the range of alternatives leading to competitive advantage - the choice of a generic (institutionalized) strategy that defends it from the forces of the industry. The variables seen under the five-forces model are essentially microeconomic in nature and the demarcation of the analytical unit (the industry) shares the same roots. 
The arguments of the Institutional Theory indicate opportunities for strategic action arising from the role of legitimacy that has an influence on the firm's economic performance. The possibility of changing the rules of the game, which were once considered socially constructed, would result in adding variables to each one of the five forces. Barriers to new entrants, for example, might be developed from institutional strategies. Based on the acknowledgement of the influence of many institutional spheres, the definition of industry structure - a core concept for this school of thought would need to be reviewed. Recursiveness and the agency-structure duality, however, weaken the model's central assumption (Structure-Conduct-Performance).

According to the Resource Based View, incorporation of the Institutional Theory has already been discussed as institutional capital, “. . . defined as the firm's capability to support valueenhancing assets and competencies. Institutional capital is the context surrounding resources and resource strategies that enhances or inhibits the optimal use of valued resource capital” (Oliver, 1997, p. 709).

In this sense, legitimacy itself tends to be seen as a resource that is non-tradeable, socially complex and built over time (Dierickx \& Cool, 1989). Legitimacy stock grows through the accumulation of flows derived from institutional strategies or the adoption of institutionalized strategies. This accumulation process, however, as discussed by Dierickx and Cool (1989), is constrained by time compression diseconomies (negative implications of a concentrated effort to gain legitimacy in Ashforth \& Gibbs, 1990), interconnected resources (multiple spheres) and causal ambiguity (limited rationality, social embeddedness, unintended consequences of action, multiple spheres).

Characterizing legitimacy as a resource would fit the attributes that define a resource as capable of generating competitive advantage under the RBV (as in Barney, 1986b, in an analysis of organizational culture as a resource). Legitimacy can create economic value (Lounsbury \& Glynn, 2001; Oliver, 1997) and is difficult to imitate, because of its accumulation process (path-dependence conditions, industry or firm evolution stage). It is not necessarily rare, but may become so in specific contexts for a certain period of time, particularly if tied in with other exclusive resources the firm may have. In addition, legitimacy, in line with the RBV's imperfect factors (resources) market assumption, and with the institutionalist view this paper presents, is not a resource whose economic rent generating potential can be known in advance.

Under the Dynamic Capabilities view, legitimacy as a meta-resource, or as a process, shaped by the firm's current position in terms or resources and evolutionary path, can more directly articulate with the institutional analysis. The focus of this Business Strategy perspective on the process of adaptation of environments undergoing rapid technological change with creative destruction dynamics (Teece, Pisano, \& Shuen, 1997), allows accommodating both (strategic) agency and structure. But this approach's Schumpeterian environment is essentially technical. Technologies change, but the rules of the game do not. Regarding these rules as socially constructed would make room for institutional strategies and for the institutional entrepreneur, removing emphasis from adapting and reconfiguring to meet environmental pressures that mainly suggests the possibility of firms adopting institutionalized strategies.

\section{LEGITIMACY AND ECONOMIC RENTS}

The theoretical view that prevails in the Business Strategy field drives managers to evaluate and implement strategies leading to achieving economic rents (monopoly, Ricardian or entrepreneurial), and essentially explores the technical environment.

Incorporating the institutional perspective as presented here suggests that legitimacy, whether as a resource, meta-resource, and whether achieved deliberately or not, be acknowledged as an axis of reference in the development of strategies by firms, and that sustained above-average returns are 
essentially dependent on the legitimacy status. We propose, therefore, the following analytical framework:

\section{Position Relative to Peer (Competitors)}

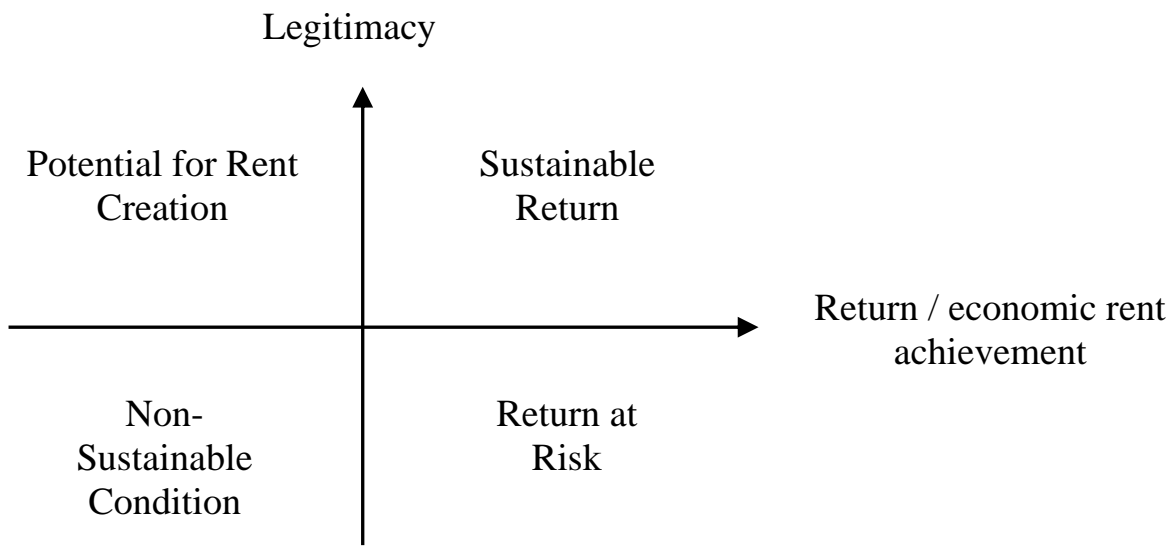

Achieving superior returns (derived from sources of economic rent) without legitimacy will leave the firm vulnerable both to institutional entrepreneurs and to other competitors, particularly those that, endowed with greater credibility or a larger stock of institutional capital, may achieve success with institutional strategies that bring about a reconfiguration of the resources base in such a manner as to become more favorable to them (for example, by means of regulatory changes, influencing public opinion, blocking access to resources etc.).

Legitimacy in and of itself is no assurance of sources of economic rent, but institutional capital can be used as a resource to forward institutional or institutionalized strategies giving access to other resources that may be sources of economic rent. Unsuccessful efforts may compromise the firm's legitimacy, leaving it in a non-sustainable situation that jeopardizes survival itself.

Lack of legitimacy, together with the lack of sources of economic rent, however, also characterizes the standing entrepreneurs or firms in emerging industries sometimes find themselves in, imposing the strategic challenge: to innovate and differentiate to obtain sources of economic rent, but, at the same time, appear as familiar, trustworthy, similar (isomorphism), in order to acquire the much-needed legitimacy.

It is not the purpose of this paper to explore every possibility and dynamic this analytical perspective offers, but only to point out the relevance of the issue of legitimacy to business strategy thinking.

\section{CONCLUSION}

The field of Business Strategy has much to gain from incorporating elements developed based on the Institutional Theory, although this view challenges the several core assumptions of prevalent schools of thought. It is perhaps because of this challenge that adopting a new view is so important.

The conception of an institutional facet of the environment, with many spheres of influence; the notion of duality in the agency-structure relationship, mediated by interpretation; the recursive nature of the institutionalization process; legitimacy as a resource, a meta-resource and the result of a process; all of these constitute a relatively new and rather complex repertoire for study, demanding new Business Strategy analysis methods and techniques. The destination is unclear, but the journey is certainly attractive. 


\section{REFERENCES}

Abrahamson, E. (1996). Management fashion. Academy of Management Review, 21(1), 254-285.

Aldrich, H. E., \& Fiol, C. M. (1994). Fools rush in? The institutional context of industry creation. Academy of Management Review, 19(4), 645-670.

Argyris, C., \& Schon, D. A. (1978). Organizational learning: a theory of action perspective. Reading, Massachussets: Addison-Wesley.

Ashforth, B. E., \& Gibbs, B. (1990) W. the double edge of organizational legitimation. Organizational Science, 1(2), 177-194.

Bain, J. S. (1956). Barriers to new competition. Boston: Harvard University Press.

Barney, J. B. (1991) Firm resources and sustained competitive advantage. Journal of Management, 17(1), 99-120.

Barney, J. B. (1986a) Strategic factor markets. Management Science, 32(10), 1231-1241.

Barney, J. B. (1986b) Organizational culture: can it be a source of sustained competitive advantage? Academy of Management Review, 11(3), 656-665.

Beckert, J. B. (1999). Agency, entrepreneurs, and institutional change: the role of strategic choice and institutionalized practices in organizations. Organization Studies, 20(5), 777-799.

Berger, P. L., \& Luckmann, T. (1998). A construção social da realidade (F. S. Fernandes, Trans.). Petrópolis: Vozes. (Original work published 1967).

Besanko, D., Dranove, D., \& Shanley, M. (2000). Economics of strategy. New York: John Wiley \& Sons.

Boyd, B. K., Finkelstein, S., \& Gove. S. (2005). How advanced is the strategy paradigm? The role of particularism and universalism in shaping research outcomes. Strategic Management Journal, 26(9), 841-854.

Caves, R. E. (1980). Industrial organization, corporate strategy and structure. Journal of Economic Literature, 18(1), 64-92.

Caves, R. E., \& Porter, M. E (1977). From entry barriers to mobility barriers: conjectural decisions and contrived deterrence to new competition. Quarterly Journal of Economics, 91(2), 241-261.

Chandler, A. D. (1962). Strategy and structure. Cambridge: MIT Press.

Coase, R (1937). The nature of the firm. Economica, 4(2), 4, 386-406.

Conner, K. R. (1991). A historical comparison of resource-based theory and five schools of thought within industrial organization economics: do we have a new theory of the firm? Journal of Management, 17(1), 121-154.

Crubellate, J. M., Grave, P. S., \& Mendes, A. A. (2004). A questão institucional e suas implicações para o pensamento estratégico. Revista de Administração Contemporânea, 8(Edição Especial), 3760.

Dierickx, I., \& Cool, K. (1989). Asset stock accumulation and sustainability of competitive advantage. Management Science, 35(12), 1504-1511.

DiMaggio, P. J (1988). Interest and agency in institutional theory. In L. G. Zucker (Ed.). Institutional 
patterns and organizations: culture and environment (pp.3-21). Cambridge, MA: Ballinger.

DiMaggio, P. J., \& Powell, W. (1983). The iron cage revisited: institutional isomorphism and collective rationality in organizational fields. American Sociological Review, 48(2), 147-169.

Elsbach; K. D., \& Sutton, R. I. (1992). Acquiring organizational legitimacy through illegitimate actions: a marriage of institutional and impression management theories. Academy of Management Journal, 35(4), 699-738.

Ghemawat, P. (2002). Competition and business strategy in historical perspective. Business History Review, 76(1), 37-74.

Giddens, A (1989). A constituição da sociedade (A. Cabral, Trans.) São Paulo: Martins Fontes. (Original work published 1984).

Granovetter, M (1985). Economic action and social structure: the problem of embeddedness. American Journal of Sociology, 91(3), 481-510.

Jaccoby, S. M. (1990). The new institutionalism: what can it learn from the old? Industrial Relations, 29(2), 316-359.

Katz, D., \& Kahn R. L (1966). The social psychology of organizations. New York: John Wiley.

Lawrence, T. B. (1999) Institutional strategy. Journal of Management, 25(2), 161-188.

Lawrence, T. B., Winn, M. I., \& Devereaux Jennings, P. (2001). The temporal dynamics of institutionalization. Academy of Management Review.The Academy of Management Review, 26(4), 624-644.

Lounsbury, M., \& Glynn, M. A. (2001). Cultural entrepreneurship: stories, legitimacy, and the acquisition of resources. Strategic Management Journal, 22(6/7), 545-564.

Machado-da-Silva, C. L., Fonseca, V. S. da, \& Crubellate, J. M (2005). Estrutura, agência e interpretação: elementos para uma abordagem recursiva do processo de institucionalização. Revista de Administração Contemporânea, 9(Edição Especial), 9-39.

March, J. G. (1978). Bounded rationality, ambiguity and the engineering of choice (in papers in honor of Herbert A. Simon). The Bell Journal of Economics, 9(2), 587-608.

Mason, E. (1939). Price and production policy of large scale enterprises. American Economic Review, 29(1), 29, 61-74.

Meyer, J., \& Rowan, B. (1977). Institutionalized organizations: formal structure as myth and ceremony. American Journal of Sociology, 83(2), 340-363.

Mintzberg, H (1978). Patterns in strategy formation. Management Science, 24(9), 934-948.

Mintzberg, H. (1990). The design school: reconsidering the basic premises of strategic management. Strategic Management Journal, 11(3), 171-195.

Mintzberg, H. (1994). The rise and fall of strategic planning. New York: Free Press.

Mintzberg, H., Ahlstrand, B., \& Lampel, J. (1998). Strategy safari: a guided tour through the wilds of strategic management. New York: Free Press.

Mintzberg, H., Ahlstrand, B., \& Lampel, J. (1998). Strategy safari: a guided tour through the wilds of strategic management. New York: Free Press.

Neilsen, E. H., \& Rao, M. V. H. (1987). The strategy-legitimacy nexus - a thick description. Academy of Management Review, 12(3), 523-533.

North, D. (1993). Institutions and economic performance. In U. Maki, B. Gustafson \& C. Knudson (Eds). Rationality, institutions and economic methodology. London: Routledge. 
Oliver, C. (1991). Strategic responses to institutional processes. Academy of Management Review, 16(1), 145-179.

Oliver, C. (1992). The antecedents of deinstitutionalization. Organization Studies, 13(4), 563-588.

Oliver, C. (1997). Sustainable competitive advantage: combining institutional and resource-based views. Strategic Management Journal, 18(9), 697-713.

Peng, M. W. (2003). Institutional transitions and strategic choices. Academy of Management Review, 28(2), 275-296.

Penrose, E. T. (1959). The theory of the growth of the firm. New York:Wiley.

Peteraf, M. A. (1993). The cornerstones of competitive advantage: a resource based view. Strategic Management Journal, 14(3), 179-191.

Pfeffer, J. (1981). Management as symbolic action: the creation and maintenance of organizational paradigms. In L. L. Cummings \& B. M. Staw (Eds). Research in Organizational Behavior (Vol. 13, pp. 1-52). Greenwich: JAI Press.

Pfeffer, J. (1993). Barriers to the advance of the organizational science: paradigm development as a dependent variable. Academy of Management Review, 18(4), 599-620.

Porter, M. E. (1980). Competitive strategy: techniques for analyzing industries and competitors. New York: Free Press.

Porter, M. E. (1985). Competitive advantage: creating and sustaining superior performance. New York: Free Press.

Pozzebon, M. (2004). The influence of a structuralist view on Strategic Management Research. Journal of Management Studies, 41(2), 247-272.

Ramos-Rodriguez, A. R., \& Ruíz-Navarro, J. (2004). Changes in the intellectual structure of strategic management research: a bibliometric study of the strategic management journal, 1980-2000. Strategic Management Journal, 25(10), 25, 981-1004.

Rumelt, R. R., Schendel, D., \& Teece, D. J. (1991). Strategic management and economics. Strategic Management Journal, 12(Special Issue), 5-29.

Schumpeter, J. A. (1934). Theory of Economic Development. Cambridge, Mass.: Harvard University Press.

Scott, W. R. (2001). Institutions and organizations. London: Sage.

Seo, M., \& Creed, W. D. (2002). Institutional contradictions, praxis and institutional change: a dialectical perspective. Academy of Management Review, 27(2), 222-247.

Sewell, W. H., Jr. (1992). A theory of structure: duality, agency, and transformation. The American Journal of Sociology, 98(1), 1-29.

Sherer, P. D., \& Lee, K. (2002). Institutional change in large law firms: a resource dependency and institutional perspective. Academy of Management Review, 45(1), 102-119.

Simon, H. (1947). Administrative behavior. New York: MacMillan.

Stinchcombe, A. L. (1965). Social structures and organizations. In J. J. March (Ed.). Handbook of Organizations (pp. 142-193). Chicago: Rand McNally \& Company.

Stone, M. M., \& Brush, C. G. (1996). Planning in ambiguous contexts: the dilemma of meeting needs for commitment and demands for legitimacy. Strategic Management Journal, 17(8), 633-652.

Suchman, M. C. (1988). Constructing an institutional ecology: notes on the structural dynamics of organizational communities. Paper presented at the annual meeting of the American Sociological 
Association. Atlanta.

Suchman, M. C. (1995). Managing legitimacy: strategic and institutional approaches. The Academy of Management Review, 20(3), 571-610.

Teece, D. J., Pisano, G., \& Shuen, A. (1997). Dynamic capabilities and strategic management. Strategic Management Journal, 18(7), 509-533.

Thompson, J. D. (1967). Organizations in action. New York: McGraw-Hill.

Vasconcelos, F. C., \& Cyrino, A. B. (2000). Vantagem competitiva: os modelos teóricos atuais e a convergência entre estratégia e teoria organizacional. Revista de Administração de Empresas, 40(4), 20-37.

Weber, M. (1999). Economia e sociedade (R. Barbosa \& K. E., Barbosa, Trans.). São Paulo: Imprensa Oficial do Estado de São Paulo. Ed. Universidade de Brasília. (Original work published 1918).

Wernerfelt, B. (1984). A resource-based view of the firm: summary. Strategic Management Journal, 5(2), 5, 171-180.

Whittington, R. (1988). Environmental structure and theories of strategic choice. Journal of Management Studies, 25(6), 521-536.

Whittington, R. (1993). What is strategy - and does it matter? London: International Thomson Business.

Whittington, R. (1992). Putting Giddens into action: social systems and managerial agency. Journal of Management Studies, 29(6), 693-712.

Williamson, O. E. The economic institutions of capitalism. New York: Free Press, 1985.

Wood, T., \& Caldas, M. (2002). Adopting imported managerial expertise in developing countries: the Brazilian experience. Academy of Management Executive, 16(2), 18-32.

Zucker, L. G. (1983). Organizations as institutions. In S. B. Bacharach (Ed.). Research in the Sociology of Organizations (pp. 1-42). Greenwitch: JAI Press. 